\title{
Epidermal Cyst in the Scrotum Successfully Treated while Preserving the Testis: A Case Report
}

\author{
Takuya Kondo $^{a}$ Takashi Kawahara $^{\mathrm{a}, \mathrm{c}}$ Taro Matsumoto $^{\mathrm{b}}$ \\ Yuko Yamamoto ${ }^{a}$ Miho Tsutsui $^{d}$ Masako Ohtani ${ }^{d}$ Mari Ohtaka $^{a}$ \\ Yohei Kumano $^{\mathrm{a}}$ Yoko Maeda ${ }^{\mathrm{a}}$ Taku Mochizuki ${ }^{\mathrm{a}}$ Kohei Mori ${ }^{\mathrm{a}}$ \\ Takuo Asai $^{\mathrm{a}}$ Shinnosuke Kuroda ${ }^{\mathrm{a}}$ Teppei Takeshima ${ }^{\mathrm{a}}$ Yusuke Hattori ${ }^{\mathrm{a}}$ \\ Jun-ichi Teranishi $^{\mathrm{a}}$ Yasuhide Miyoshi ${ }^{\mathrm{a}}$ Yasushi Yumura ${ }^{\mathrm{a}}$ \\ Masahiro Yao ${ }^{c}$ Yoshiaki Inayama $^{b}$ Hiroji Uemura $^{a}$ \\ Departments of ${ }^{a}$ Urology and Renal Transplantation, and ${ }^{b}$ Pathological Diagnosis, \\ Yokohama City University Medical Center, ' Department of Urology, Yokohama City \\ University Graduate School of Medicine, and ${ }^{d}$ Department of Urology, Yokohama Toho \\ Hospital, Yokohama, Japan
}

\section{Key Words}

Epidermal cyst $\cdot$ Epidermoid cyst $\cdot$ Scrotum $\cdot$ Scrotum mass

\begin{abstract}
A 66-year-old male was referred to our hospital for further examination of a scrotal mass. Because of the risk of testicular cancer, we first clamped the vessels as a course of higher orchiectomy. Then, we approached the tumor through the scrotum and successfully resected it while preserving the testis. A histopathological diagnosis revealed an epidermal cyst. We herein report a rare case of an intrascrotal epidermal cyst successfully treated while preserving the testis.

(C) 2016 The Author(s)

Published by S. Karger AG, Basel
\end{abstract}

\section{Introduction}

Epidermal cysts are the most common benign epithelial cysts and are generally thought to have nonmalignant potential [1]. In most cases, epidermal cysts usually occur in the skin of the scalp, ear, face, and back [2]. We herein report an uncommon benign entity of an epidermal cyst in the scrotum.

\section{KARGER}

Takashi Kawahara, MD

Department of Urology and Renal Transplantation

Yokohama City University Medical Center

4-57, Urafune-cho, Minami-ku Yokohama (Japan)

E-Mail kawahara@yokohama-cu.ac.jp 


\section{Case Reports in Oncology}

Kondo et al.: Epidermal Cyst in the Scrotum Successfully Treated while Preserving the Testis: A Case Report

\section{Case Presentation}

A 66-year-old man was referred to our hospital for further examination of a right scrotal mass. One year before his initial visit, he had noted the right scrotal mass, which had gradually increased. The mass was separated from the testis and epididymis with rubber hardness. He had no remarkable past history except for hyperlipidemia, diabetes mellitus, and hypertension.

Laboratory Data and Imaging Findings at the Time of Admission

The hematological and biochemical data showed no abnormal findings. Tumor markers of testicular cancer were also within normal limits (HCG $<0.1 \mathrm{mIU} / \mathrm{ml}$, HCG- $\beta<0.1 \mathrm{ng} / \mathrm{ml}$, AFP $5 \mathrm{ng} / \mathrm{ml}$, and LDH $170 \mathrm{U} / \mathrm{l}$ ). Ultrasonography and MRI showed a scrotum mass separated from the testis (fig. 1, fig. 2).

\section{Operative Procedure}

In December 2015, the patient underwent mastectomy of the scrotum (fig. 3). To avoid the risk of dissemination if the mass was adherent to the testis as a testicular tumor, we first secured the spermatic cord until we could confirm the separation between the testis and the mass. Then, we performed a pathological diagnosis on a frozen section to rule out malignancy. Due to the diagnosis of an epidermal cyst, we resected the intrascrotal mass with the adhering skin.

\section{Pathological Findings}

The resected mass weighed $169 \mathrm{~g}$ and measured $11.0 \times 7.5 \times 1.0 \mathrm{~cm}$ (fig. 4). It was cystic and contained keratotic fluid. Histologically, the cyst wall was covered with keratinizing squamous epithelium without atypia (fig. 5).

\section{Postoperative Course}

No adverse perioperative event was observed. The patient has not experienced recurrence for 4 months following the resection of the intrascrotal mass.

\section{Discussion}

Epidermal cysts are the most common benign epithelial cysts and are generally devoid of malignant potential [1]. They consist of a sac lined by stratified squamous epithelium filled with laminated keratin, cholesterol crystals, and debris [3, 4].

Epidermal cysts are approximately twice as common in men as in women [5]. They typically occur in the skin of the scalp, ear, face, and back [2]. In the urological field, epidermal cysts have been reported in the perineum, penis, testis, and scrotum. Only 25 cases of epidermal cysts in the scrotum have been reported in Japan [6].

On MRI, epidermal cysts are described as high-intensity, well-defined solid masses surrounded by a low-signal capsule on T2-weighted imaging [7]. Our case showed the same findings. Although patients may present with these findings, the preoperative diagnosis of an epidermal cyst is very difficult, especially in the scrotum. According to some reports, epidermal cysts in the scrotum were resected with the testis under a suspicion of testicular cancer [8].

Although the prognosis is good and epidermal cysts are considered not to have malignant potential, malignant transformations of basal cell carcinoma or squamous cell carcino- 
Kondo et al.: Epidermal Cyst in the Scrotum Successfully Treated while Preserving the Testis: A Case Report

ma from epidermal cysts have been reported [9]. Complete local excision is considered to be the treatment of choice for an epidermoid cyst, and careful observation is required $[10,11]$.

\section{Conclusion}

We herein described a case of an epidermal cyst that was successfully resected while preserving the testis.

\section{Statement of Ethics}

Written informed consent was obtained from the patient in this study.

\section{Disclosure Statement}

The authors declare that they have no competing interests.

\section{References}

1 Prasad KK, Manjunath RD: Multiple epidermal cysts of scrotum. Indian J Med Res 2014;140:318.

2 Ohyama C, Tochigi T, Kuwahara M, Imai Y: Intrascrotal epidermoid cyst: report of two cases. Int J Urol 1996;3:245-247.

-3 Correa AF, Gayed BA, Tublin ME, Parwani AV, Gingrich JR: Epidermal inclusion cyst presenting as a palpable scrotal mass. Case Rep Urol 2012;2012:498324.

4 Shah KH, Maxted WC, Chun B: Epidermoid cysts of the testis: a report of three cases and an analysis of 141 cases from the world literature. Cancer 1981;47:577-582.

5 Jeyaraj P, Sahoo NK: An unusual case of a recurrent seborrheic/epidermal inclusion cyst of the maxillofacial region. J Maxillofac Oral Surg 2015;14(suppl 1):176-185.

6 Tamada S, Wada S, Yoshimura R, Yamamoto K, Kishimoto T: Intrascrotal epidermoid cyst: report of two cases. Hinyokika Kiyo 1999;45:285-288.

7 Cho JH, Chang JC, Park BH, Lee JG, Son CH: Sonographic and MR imaging findings of testicular epidermoid cysts. AJR Am J Roentgenol 2002;178:743-748.

8 Kawai N, Sakagami H, Awata S, Kojima Y, Tatsura H, Sasaki S: Epidermoid cyst of the scrotum: a case report. Hinyokika Kiyo 1996;42:609-611.

19 Miller JM: Squamous cell carcinoma arising in an epidermal cyst. Arch Dermatol 1981;117:683.

10 Lee SJ, Lee JH, Jeon SH, Kim MJ: Multiple epidermoid cysts arising from the extratesticular scrotal, spermatic cord and perineal area. Korean J Urol 2010;51:505-507.

-11 Lim J, Cho K: Epidermoid cyst with unusual magnetic resonance characteristics and spinal extension. World J Surg Oncol 2015;13:240. 


\section{Case Reports in Oncology}

\begin{tabular}{l|l}
\hline Case Rep Oncol 2016;9:235-240 \\
\hline DOI: 10.1159/000445826 & $\begin{array}{l}\text { (c) 2016 The Author(s). Published by S. Karger AG, Basel } \\
\text { www.karger.com/cro }\end{array}$ \\
\hline
\end{tabular}

Kondo et al.: Epidermal Cyst in the Scrotum Successfully Treated while Preserving the Testis: A Case Report

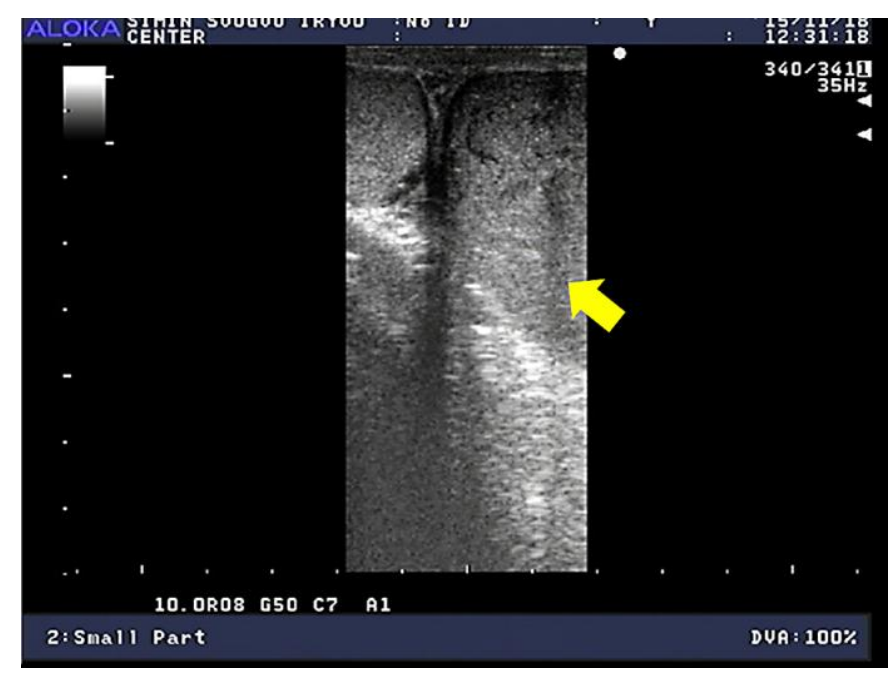

Fig. 1. Ultrasound findings revealed that the intrascrotal mass (measuring $8 \mathrm{~cm}$ in diameter) showed uniformity with a low-echoic lesion (arrow).

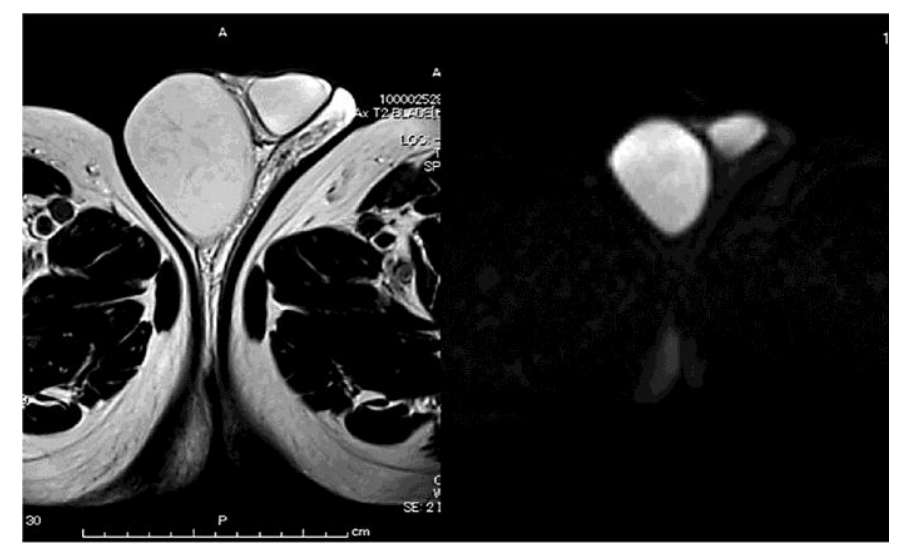

Fig. 2. T2-weighted (left) and diffusion-weighted (right) MR images. The mass was separated from the testis with high signals in the T2-weighted image. 


\section{Case Reports in Oncology}

\begin{tabular}{l|l}
\hline Case Rep Oncol 2016;9:235-240 \\
\hline DOI: 10.1159/000445826 & $\begin{array}{l}\text { (c) 2016 The Author(s). Published by S. Karger AG, Basel } \\
\text { www.karger.com/cro }\end{array}$ \\
\hline
\end{tabular}

Kondo et al.: Epidermal Cyst in the Scrotum Successfully Treated while Preserving the Testis: A Case Report

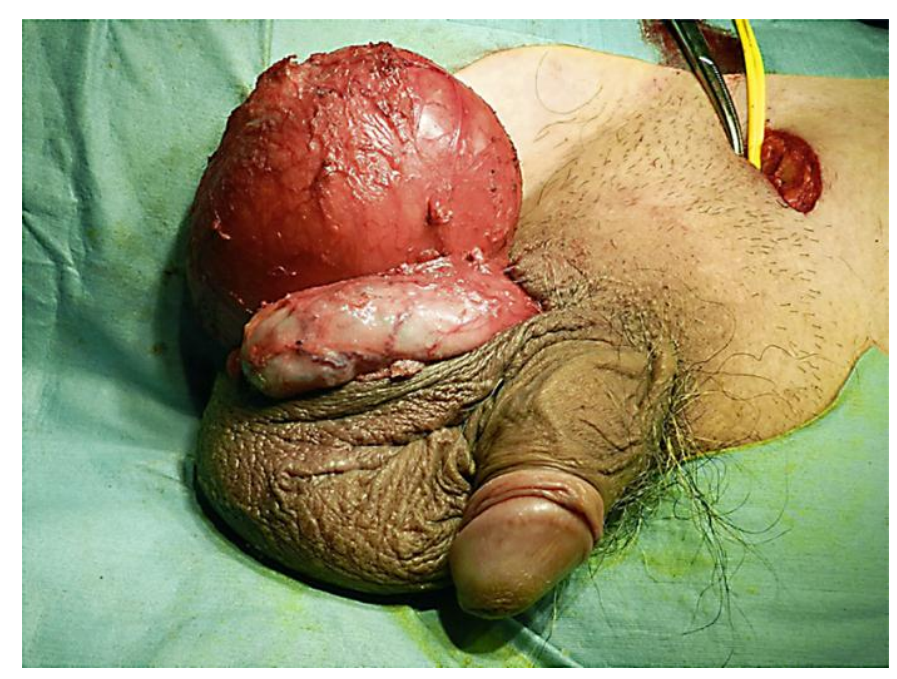

Fig. 3. Intraoperative findings. The mass was separated from the testis.

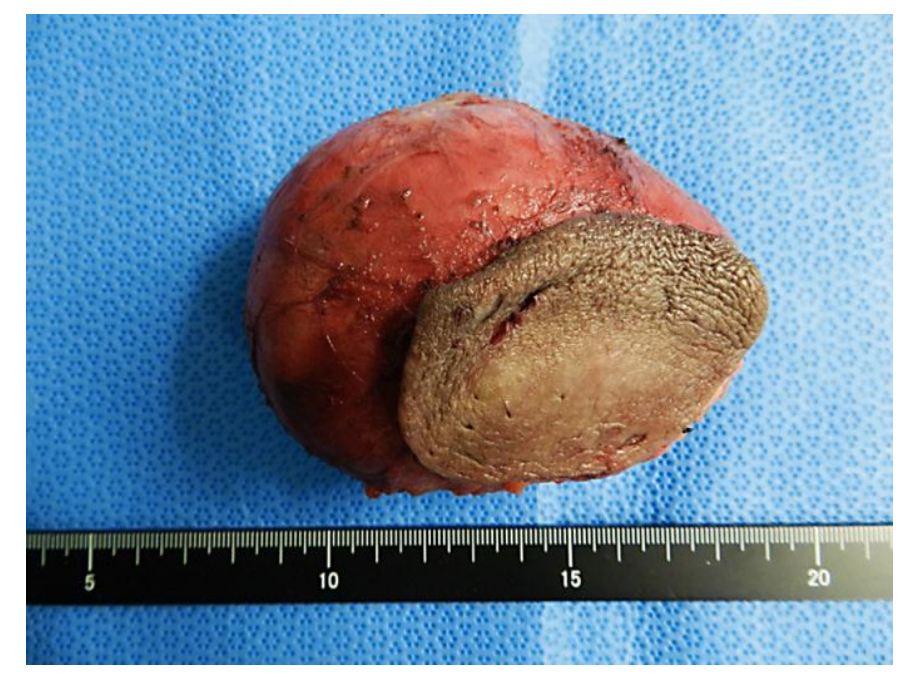

Fig. 4. A surgical specimen of the intrascrotal mass resected with the skin. 


\section{Case Reports in Oncology}

\begin{tabular}{l|l}
\hline \multicolumn{2}{l|}{ Case Rep Oncol 2016;9:235-240 } \\
\hline DOI: 10.1159/000445826 & $\begin{array}{l}\text { C 2016 The Author(s). Published by S. Karger AG, Basel } \\
\text { www.karger.com/cro }\end{array}$ \\
\hline
\end{tabular}

Kondo et al.: Epidermal Cyst in the Scrotum Successfully Treated while Preserving the Testis: A Case Report

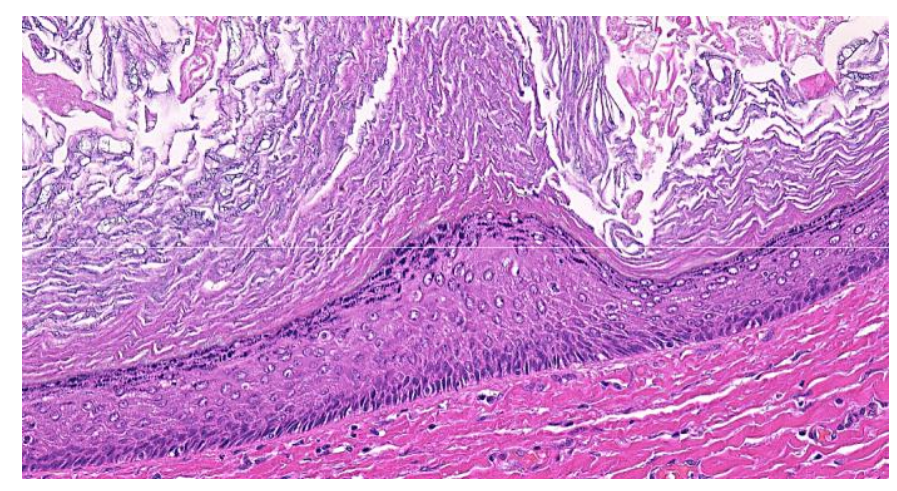

Fig. 5. Histologically, the cyst contained keratin flakes and its wall was covered with keratinizing squamous epithelium. 